Research.

\title{
THE EFFECT OF THE TOTAL CREDIT RECEIVABLE UPON THE REVENUE OF CREDIT SERVICE AT KPRI-KPDK IN SUKABUMI
}

\author{
Nani Pujiastuti \\ Lecturer at Politeknik BBC Sukabumi
}

\begin{abstract}
The influence of the number of credit receivable against the revenue of the credits services at KPRI-KPDK in Sukabumi". The Credit receivable at KPRI$K P D K$ in Sukabumi is an indication that an increasing does not mean positive one because it showed that the volume activities services has been arisen however the increasing receivable having a risk, therefore KPRI-KPDK in Sukabumi has a lot of things to reconsider in determining the procedure of the credit given.

This research has identified how the influence of a credit against the revenue of the services at KPRI-KPDK in Sukabumi The data used is the primary data which is the data refers to the Report of the Annual Members Meeting (RAT) at KPRI-KPDK in Sukabumi. The research data refers to: financial report which is the balance sheets for five years from 2008 up to 2012 related to the end year of the responsibility report of KPRI-KPDK in Sukabumi and this report is expected to figure out the cooperation unit accordingly.

This research has been indicating the numbers of receivable credits as KPRIKPDK has been increased during 2008-2009, although in 2010, it was decreased but the following years of 2011-2012 it has increased The revenue of the credit service at KPRI-KPDK in Sukabumi has been increasing each year, though it is not quite significant in percentage but it is quite stable ever since

The influence of the amount of the total loan against the revenue of the credit service has been positive which $r=0.840$ indicating that the variable $x$ has been affecting significantly against the-the number of the receivable credit variables $y$ or the revenue of the credit service which is $6 \%$. The Data of the calculation analysis has obtained $y$ regression equation $=39.852 .081,767+0,123(X)$. It means that every 1.00 of the number of receivable credit will affect the revenue of credit services amounting to $R p 0.123,00$.

Thus writer has been able to make a conclusion that the total amount of the credit receivable has been affecting the revenue of the credit services at KPRIKPDK in Sukabumi accordingly.
\end{abstract}

Keywords: credit receivable and revenue services credit

\section{INTRODUCTION}

\section{Background}

The development of the strategic national economics and the environment changes in business either banking sectors or non banking sectors including cooperation units as well as small and medium ones have been running quite fast and dynamic. KPRI-KPDK in Sukabumi is a business unit that can improve the people income and their welfare and can make them solving their economical problems and social diversity so that it can be the place for the people to perform their economics business.

PRI-KPDK Cooperation in Sukabumi is a financing authority non-bank which is its core business is providing the financial loan and savings for the clients which is in 
compliance with the applicable regulation stipulated by the government.

Providing the credit facilities, KPRI-KPDK Cooperation unit in Sukabumi is having the objective to use its capital to support the members welfare. Furthermore the cooperation unit has a continuous improvement function, so that a clear revenue resources is required which is a credit loan unit has been defined to obtain an economics profit refers to the revenue of the credit service.

Moreover, based on the Banking Regulation no. 7 year 1998:

"A Credit is a supply or a payment of the debt which is equal to it which is in compliance with the credit agreement between a bank and other party that has obliged the creditor to settle the credit on a certain limited time agreed including the credit interest, rewards or profit sharing.

Based on the aforementioned credit understanding, a credit is a loan given by KPRI-KPDK in Sukabumi to the clients who are obliged to pay the interest, give the reward or profit sharing which is the revenue of the cooperation unit due to the utilization of its capital accordingly.

In general, a credit terms has appeared due to the credit transaction happened in a company. This kind of credit transaction is not going to be a direct cash income, but it will create a credit amount to be settled down and will be a cash receivable as soon the related credit amount is paid.

In connection with the aforementioned understanding, the writer has assumed that the more working capital has been provided by the cooperation, the bigger revenue will be received.

The revenue of the service is the most important aspect of a company, as without having a revenue it is not going to get any profit or income.

Credit business either credit selling or credit loan has its own risk due to the creditors might not be able to pay the total amount of the credit loan completely.

As an alternative payment of the credit amount, the cooperation of KPRI-KPDK in Sukabumi has had a concept dealing with a maximum effort to collect, manage and redistribute the related amount.

The credit is an active asset and it has been considered a rapid asset turnover which is less than one year. Though, the credit is a reliable asset turnover, the financing support to deliver the credit is necessary to be provided and it should be for a long-term period.

The credit delivery could create a lot of problems related to the revenue. Delivering the huge amount of the credit will create big amount of the credit payment to be settled down, and most of them are not running very well. Of course it will affect the running of the credit facility at the cooperation and it will obviously make KPRI-KPDK in Sukabumi suffering the revenue losses of the credit service itself.

Such a revenue is very crucial for all companies due to their investment program. In this case, any net assets changes occurred due to the production activity and the profit and losses which are from assets selling and investment will affect the revenue of the company.

In accordance with the aforementioned background, the cooperation as a finance institution should have to be careful and selective to provide a credit facility in order to avoid and minimize any credit risk would appear and finally people will trust to the cooperation itself better.

In relation with the aforementioned problems, the writer is interested in doing a research about "The Effect of Credit Amount upon the Revenue of the Credit Service at KPRI-KPDK in Sukabumi". 


\section{Problems Identification}

The following problems identified are as follows:

1. How big is the total amount of the credit loan provided at KPRI-KPDK in Sukabumi?

2. How much is the total amount of the revenue of credit service received at KPRIKPDK in Sukabumi?

3. How has the effect of the credit affected the revenue of the credit service at KPRIKPDK in Sukabumi?

\section{The Objectives of the Research.} follows:

In compliance with the problems identified, the objectives of the research are as

1. To recognize the total amount of the credit at KPRI-KPDK in Sukabumi.

2. To recognize the revenue of the credit services at KPRI-KPDK in Sukabumi.

3. To recognize the effect of credit amounr upon the revenue of the credit services at KPRI-KPDK in Sukabumi.

\section{Opinion Framework}

A cooperation activity is connected with the financing distribution to the clients which is savings and loans facility, so that providing a credit should have to respect to a clear and applicable regulations to avoid or minimize a credit risk because the cooperation objective is gaining a profit.

Referring to the previous description, a credit is an exhanging or transfering the precious things such as money, goods or services that could be paid at the future value.

The revenue of the credit services is a resource of a revenue of a credit service received by the cooperation. So that, the bigger amount of a credit is given, the more revenue of the cooperation will get.

The revenue of the credit service is very important related to the financial report, because the management of the cooperation is interested in finding out how much amount of the revenue it gained which is in compliance with the applicable general principles of the accountancy within a certain period of time.

Based on the aforementioned descriptions, the connection between the credit loan and the revenue of the credit services could be described as follows:

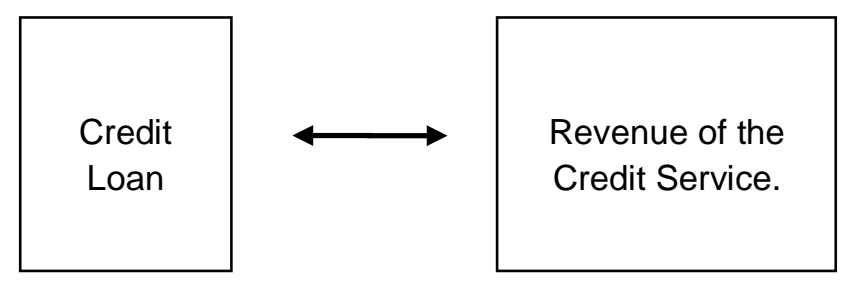

Picture 1: Opinion Framework

\section{Location and Time Schedule of the Research}

The research had taken place at KPRI-KPDK in Sukabumi at Jalan Surya Kencana No.78. Telp. (0266) 222407. Sukabumi 43113 during April 2013 to June 2013.

Nani Pujiastuti: The Effect of The Total Credit Receivable Upon The Revenue of Credit Service at KPRI-KPDK in Sukabumi 


\section{RESEARCH METHODOLOGY}

\section{Research Design and Hypothesis}

\section{Research Design}

Research design is an approach done by the writer to perform the practical ways dealing with an object which is the problem. The writer has applied associative method to identify the connection of two or more variables which is an approach finding out the correlation between the variable $X$ (independent) and variable $Y$ (dependent). Sugiyono (2010:89) defined that associative is"an identification that has predicted a correlation between two variables or more occured"

The correlation of the inter variables is a causal correlation which is a cause-effect correlation, when the variable $\mathrm{X}$ (independent) is increased or decreased, the variables $\mathrm{Y}$ (dependent) will increase or decrease too.

Therefore, the research design could be formulated as the following:

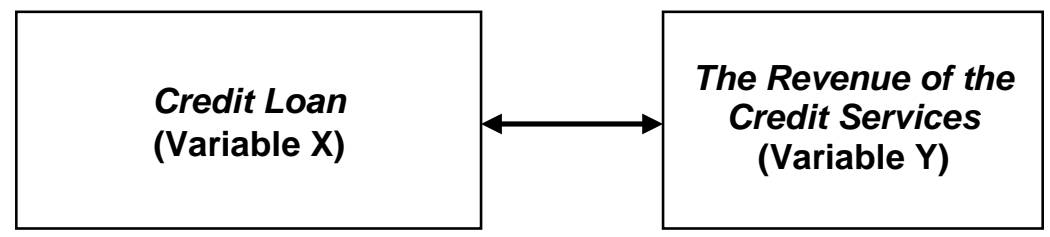

Picture 2 : Research Design

Refers to the research designed, so the hypothesis is that the total amount of the credit loan has affected the revenue of the credit service.

The hypothesis is a temporary response that has to be examined whether it is true or not, in order to prove that the hypothesis is true, the writer is going to study more over about whether the amount of the credit loan as independent variable has affected the revenue of the credit service as dependent variable.

Based on the aforementioned research design, the writer aims to find out the effect of the amount of the credit loan upon the revenue of the credit service. So that the hypothesis could be formulated as the following statistics equation:

$H_{0}=T$ no positive effect has happened between the total amount of the credit loan upon the revenue of the credit service.

$\mathrm{H}_{1}=\mathrm{A}$ positive effect has happened between the amount of the credit upon the revenue of the credit service.

\section{Research Method}

A method is a procedure or a scientific way to discover something. A research is a systematical and logical process of the data collection and analysis to achieve the certain objectives. Researching is finding out an accurate data analyzed.

Sugiyono (2012:2) defined that 'the research method is a scientific way to obtain the data due to a certain objective and purpose'. This understanding has several key words which is scientifics, data, objective and purpose.

1. Scientifics means that a research is based on a scientific symptom which is rational, empirics and systematic.

2. Data, this research has empirics data, valid criteria and reliable.

3. Obejctive. The research has a certain objective based on the evidence, proven and development.

4. Purpose. This research is expected to be useful for the particular party.

Nani Pujiastuti: The Effect of The Total Credit Receivable Upon The Revenue of Credit Service at KPRI-KPDK in Sukabumi 


\section{Data Analysis}

Primary data has been obtained based on the Report of the Members Annual Meeting at KPRI-KPDK in Sukabumi. Data of the research are related to the Balance Report for 5 years during 2008 to 2012 which is expected to determine the condition of the cooperation.

Data collection technique based on:

1. Library Research

Library Research which is a research method studying some books, literatures related to the study being researched.

2. Documentation Study. in Sukabumi.

Is a method studying some papers and documentations related to KPRI-KPDK

\section{Research variable and Operational variable.}

\section{Research Variable.}

The writer has identified the title of this research is about the Effect of the Total Amount of the credit loan upon the Revenue of the Credit Service. To ease the research and to obtain the data more accurate and effective, the writer has applied two variables which is independent variable and dependent variable.

According to Sugiyono (2008:38) variable of the research is any kind of the things that have been identified to be studied in order to get the information about the related subjects which could be concluded afterwards.

Independent variable, according to Sugiyono is the variable that has been affecting or changing another variable to be a dependent variable.

Independent variable is a part of variable $X$ which is the credit amount. Variable $X$ is the variable that has been affecting other is named a cause variable.

Dependent variable is a variable depending to other variable. According to Sugiyono (2006:33) dependent variable is a variable being affected by independent variable. Dependent variable is variable $Y$ which is the revenue of credit services or profitability credit.

\section{Operational Variable.}

An operational variable is the way how to measure a concept and how a concept is being measure to produce the variables which have been affecting one to another.

Suharsimih Arikunto defined, variables are research objects to study, or the core intention of a research.

The function of variable $X$ is the total amount of credit loan relating to several analysis about how huge level of the credit has happened at KPRI-KPDK in Sukabumi which has been studied using two dimensions or two indicators. And the function of Variable $Y$ is the level of the revenue of the credit service which has been studied based on the applicable system at KPRI-KPDK in Sukabumi as the comparison one to increase the revenue by anticipating and minimizing the problems that will be appeared.

In order to reach the aims of this research the writer will describe the extent of the related variables. The extents of the variables are as follows:

Nani Pujiastuti: The Effect of The Total Credit Receivable Upon The Revenue of Credit Service at KPRI-KPDK in Sukabumi 
Table 1

Operational Variables

\begin{tabular}{|c|c|c|c|c|}
\hline Variable & Definition & Dimension & Indicator & Scale \\
\hline $\begin{array}{l}\text { Credit } \\
\text { Loan } \\
\text { (X) }\end{array}$ & $\begin{array}{l}\text { A credit is an } \\
\text { amount to be paid by } \\
\text { other party due to its } \\
\text { due date of the } \\
\text { payment. M. } \\
\text { Munandar (2006:77) }\end{array}$ & $\begin{array}{l}\text { Total amount of the } \\
\text { credit loan within a } \\
\text { year. }\end{array}$ & $\begin{array}{l}\text { Credit balance } \\
\text { on the } \\
\text { Balance Sheet }\end{array}$ & Ratio \\
\hline $\begin{array}{l}\text { Revenue } \\
\text { of Credit } \\
\text { Service } \\
\text { (Y) }\end{array}$ & $\begin{array}{l}\text { Revenue is an } \\
\text { increasing of total } \\
\text { assets that has } \\
\text { impacted the } \\
\text { increasing of owners' } \\
\text { equity instead of } \\
\text { new capital invested } \\
\text { or additional assets } \\
\text { due to a liability } \\
\text { increased. } \\
\text { M. Munandar } \\
\text { (2006:18) }\end{array}$ & Business Revenue & $\begin{array}{l}\text { Total amount } \\
\text { of the revenue } \\
\text { of the credit } \\
\text { service whithin } \\
\text { a year. }\end{array}$ & Ratio \\
\hline
\end{tabular}

\section{The Research Instruments}

This research is about an analysis of the credit amount upon the effect of the revenue of the credit services as follows:

\section{Data Collection Instrument}

Data collection instrument of this research is based on The Financial Report of KPRI-KPDK In Sukabumi during 2008 to 2012, specifically the Profit and Losses Report in the Balance Sheet Report of KPRI-KPDK in Sukabumi.

\section{The Procedure of the Data Collection}

Getting the data required for this research, the writer should have to do some steps which is a documentation study to perform the research or to collect some related material, field data. After having collected the data required then the writer analyzed them to identify the value of variable $(X)$ and variable $(Y)$.

In order to have this research which is in compliance with the aims of the research and the procedure of the data collection, then valid and reliable data can determine the result of the research is true.

\section{Technique of the Data Analysis}

\section{Correlation Analysis}

To identify how big the correlation between the credit amount and the revenue of the credit service has happened, the calculation has applied an equation refers to Sugiyono (2008:248) which is the analysis of a tight correlation between variable $(\mathrm{X})$ and variable $(\mathrm{Y})$, as follows:

$$
\mathrm{r}=\frac{n \cdot \sum x \cdot y-\sum x \sum y}{\sqrt{n \sum x^{2}-\left(\sum x\right)^{2}\left(n \sum y^{2}-\left(\sum y\right)^{2}\right)}}
$$


Note:

$$
r=\text { Correlation Coefficient }
$$

$r$ value has indicated that the correlation between the independent variable $(X)$ and dependent variable $(Y)$ is about 0 and $(0<r<1)$. Where $X$ is a quantitative capital investment and $Y$ is a probability ratio.

Correlation is a kind of form being used to identify the effect of the intervariables. They considered having been correlated when the variable $X$ has been changed and followed by the variable $Y$ regularly and at the same direction or can be at the opposite one, nevertheless a coefficient is a measurement of how big or small, or, how strong or not strong the variable $\mathrm{X}$ against the variable $\mathrm{Y}$.

The quality of the correlation has been identify in the coefficient index which is within an interval between -1 up to +1 refers to the tightness of the correlation based on the interpretation of Sugiono (2006:216), as the following:

Table 2 Interpretation of the Correlation Coefficient

\begin{tabular}{|c|c|c|}
\hline No & $\begin{array}{c}\text { Coefficient } \\
\text { Interval }\end{array}$ & Correlation level \\
\hline 1 & $0,00-0,19$ & The lowest \\
\hline 2 & $0,20-0.39$ & low \\
\hline 3 & $0,40-0,59$ & Stronger \\
\hline 4 & $0,60-0,79$ & Strong \\
\hline 5 & $0,80-1,00$ & The strongest \\
\hline
\end{tabular}

When the number is a negative one, it means a negative correlation has happened, it indicates that the increasing level has happened. Correlation Index has never been more than 1.

\section{Determinant Coefficient}

The determinant coefficient or the determining coefficient has been applied to indicate the level of how strength is the effect of inter-variables in a percentage (\%) contribution of variable $X$ can affect the up and down level of the variable $Y$, this value has been determined using $D$ notation where $D=r^{2}$ and the correlation between the determinant coefficient can be formulated as follows:

$K D=r^{2} \times 100 \%$

$r=$ correlation coefficient

\section{Regression Analysis}

Regression Analysis is a correlation between the variables oriented to a causeeffect relationship. Regression term is a prediction or estimation.

In order to identify the regression value, a regression coefficient is applied which is the $Y$ variable changes has happened due to $X$ variable changes at any unit of regression analysis which is the function of mathematics $Y=a+b(X)$ and the equations are as follows:

b $=\frac{\mathbf{n} 2 X Y-2 X 2 Y}{n \sum X Y^{2}-\left(\sum x\right)^{2}}$

Nani Pujiastuti: The Effect of The Total Credit Receivable Upon The Revenue of Credit Service at KPRI-KPDK in Sukabumi 


$$
\begin{aligned}
& \mathbf{a}=\frac{2 Y-b \cdot 2 \mathrm{X}}{\mathbf{n}} \\
& X=\text { independent variable } \\
& Y=\text { dependent variable } \\
& \mathrm{a}=\text { constant value } \\
& \mathrm{b}=\text { coefficient of the regression } \\
& \mathrm{n}=\text { Total data }
\end{aligned}
$$

\section{Hypothesis Test}

Hypothesis test has applied a significant value obtained from the table of the regression result calculated by the SPSS (Statistical Package for Science and Society) computer program.

The aforementioned hypothesis test has applied P-Value, when the hypothesis is accepted, a significant value obtained is less than 0.05 or $P<0.05$, it explains that $\mathrm{H}_{0}$ is rejected and $\mathrm{H}_{1}$ is accepted. And on the contrary, when a hypothesis is rejected, the significant value is more than 0.05 or $P>0.05$, so that $H_{0}$ is accepted and $H_{1}$ is rejected.

\section{RESULT OF THE RESEARCH}

\section{The total amount of the credit at KPRI-KPDK in Sukabumi.}

Identifying the total amount of the credit at KPRI-KPDK in Sukabumi, the writer has taken the data of the Financial Report especially the data about the total amount of the credit during 2008 - 2012 which has been indicated on the calculation table as follows:

Table 3

Total of the credit at KPRI-KPDK in Sukabumi

\begin{tabular}{|c|r|r|}
\hline $\begin{array}{c}\text { Year } \\
\text { 2008-2012 }\end{array}$ & Credit Amount & $\begin{array}{c}\text { Increase } \text { I } \\
\text { Decrease }\end{array}$ \\
\hline 2008 & $425,158,637$ & 234.0469 \\
\hline 2009 & $515,574,461$ & 121.2664 \\
\hline 2010 & $370,502,080$ & 71.86199 \\
\hline 2011 & $901,553,879$ & 243.333 \\
\hline 2012 & $1,140,768,858$ & 126.5336 \\
\hline
\end{tabular}

Sources: The Financial Report of the Annual Members Meeting at KPARI-KPDK in Sukabumi during 2008 -2012 explains it.

Having more clear description about the total of the credit, the following graph 


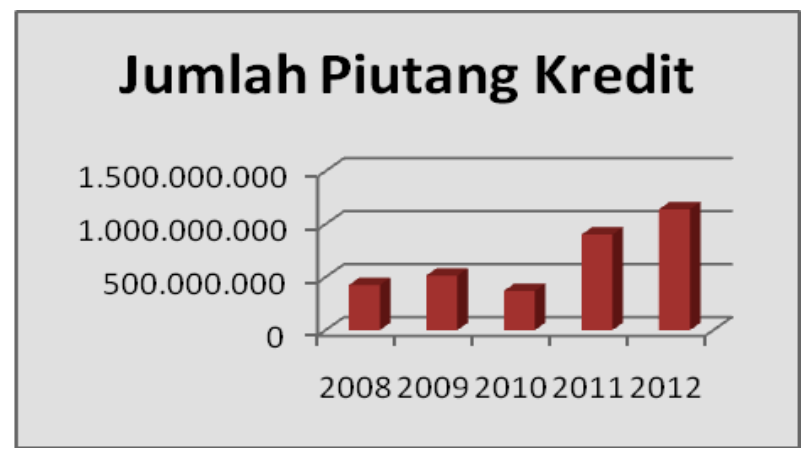

Drawing 3

Total amount of the credit loan at KPRI-KPDK in Sukabumi during 2008 - 2012

The graph aforementioned has explained that the total amount of credit loan at KPRI-KPDK in Sukabumi for the last five years indicating that it has been increasing continuously, however in 2010 the amount of the credit was slightly decreased, but in

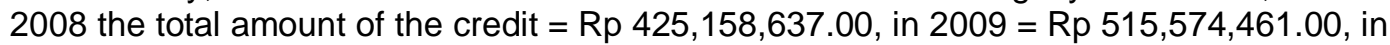
$2010=R p 370,502,080.00$, in $2011=R p 901,553,879.00$ and in $2012=R p$ $1,140,768,858.00$.

\section{The Revenue of the Credit Service at KPRI-KPDK in Sukabumi.}

The revenue is a financial income due to the company's activity refers to sales income, fees, interest, dividend, royalty, and rental.

Data obtained is the data of the revenue of the credit service for 5 years during 2008 - 2012 and it has been calculated using mathematics equations to identify any changes of yearly credit service.

Table 4

The Revenue of the credit service at6 KPRI-KPDK in Sukabumi during $2008-2012$

\begin{tabular}{|c|r|r|}
\hline Year & \multicolumn{1}{|c|}{ Revenue } & $\begin{array}{c}\text { Increase / } \\
\text { Decrease }\end{array}$ \\
\hline 2008 & $60,751,882$ & 279.1396 \\
\hline 2009 & $105,565,480$ & 173.765 \\
\hline 2010 & $118,751,969$ & 112.4913 \\
\hline 2011 & $129,225,744$ & 108.8199 \\
\hline 2012 & $195,949,341$ & 151.6334 \\
\hline
\end{tabular}

Source : The Financial Report of the Annual Members Meeting in Sukabumi during 2008-2012

Nani Pujiastuti: The Effect of The Total Credit Receivable Upon The Revenue of Credit Service at KPRI-KPDK in Sukabumi 


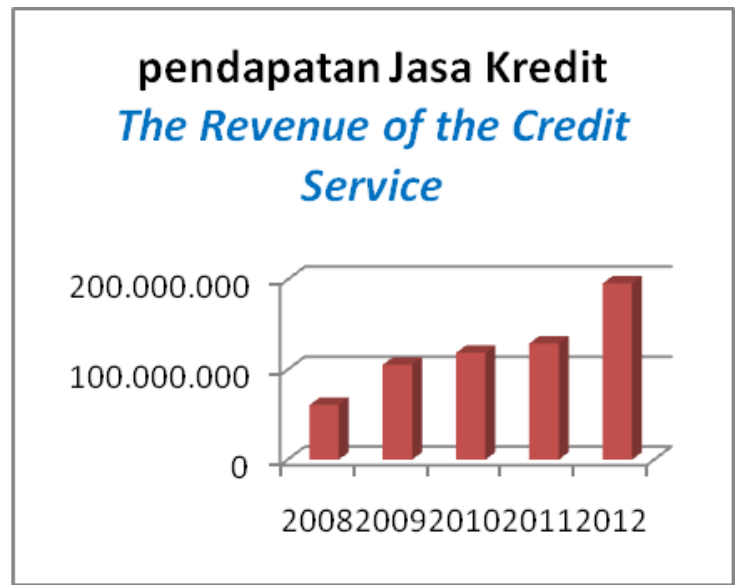

\section{Picture 4 \\ The revenue of the credit service at KPRI-PDKP in Sukabumi}

In 2008-2012

Referring to the revenue of the credit service received at KPRI-KPDK in Sukabumi which is it has been improving continuously, in $2008=\mathrm{Rp} 60,751,882,00$, in $2009=\mathrm{Rp}$ 105,565,480, in $2010=\mathrm{Rp} 118,751,969,00$, in $2011=\mathrm{Rp} 129,225,744$ and in $2012=\mathrm{Rp}$ $195,949,341$.

The Effect of the Total Amount of the Credit upon the Revenue of the Credit Service at KPRI-KPDK in Sukabumi.

In order to identify the total amount of the credit affecting the revenue of the credit service at KPRI-KPDK in Sukabumi during 2008 to 2012, a quantitative examination should have to be done. The data required are as follows:

Table 5

The Data of the total amount of the credit and the revenue of the credit service at KPRI-KPDK in Sukabumi in 2008 - 2012

\begin{tabular}{|r|r|r|}
\hline Year & Credit Loan & $\begin{array}{r}\text { Revenue of } \\
\text { the service }\end{array}$ \\
\hline 2008 & $425,158,637$ & $60,751,882$ \\
\hline 2009 & $515,574,461$ & $105,565,480$ \\
\hline 2010 & $370,502,080$ & $118,751,969$ \\
\hline 2011 & $901,553,879$ & $129,225,744$ \\
\hline 2012 & $1,140,768,858$ & $195,949,341$ \\
\hline
\end{tabular}

The aforementioned data is the total amount of the credit loan and the revenue of credit service for the last 5 years, both variables have been increasing obviously.

Testing the data has applied the following analyses;

\section{Correlation Analysis}

The correlation analysis has been applied to identify the correlation between the total amount of the credit and the revenue of the credit service and it has applied 
SPSS program (Statistical Package for Science and Society) and the results are as follows;

Table 6

Correlations

\begin{tabular}{|c|c|c|c|}
\hline & & $X$ & $Y$ \\
\hline X & $\begin{array}{l}\text { Pearson } \\
\text { Correlation } \\
\text { Sig. (2-tailed) } \\
\text { N } \\
\text { Pearson } \\
\text { Correlation } \\
\text { Sig. (2-tailed) } \\
\text { N }\end{array}$ & $\begin{array}{r}1 \\
\\
5 \\
.840 \\
.075 \\
5\end{array}$ & $\begin{array}{r}.840 \\
.075 \\
5 \\
1\end{array}$ \\
\hline
\end{tabular}

Correlation is significant at the 0.01 level (2-tailed).

Based on the aforementioned result of analysis using SPSS, it has explained that the correlation of $(X)$ value and $(Y)$ is 0.840 , it means that the correlation between the amount of the credit and the revenue of credit service is quite high and it has a positive correlation explaining that each credit amount has affected the revenue of the credit service refers to Sugiyono in the previous chapter.

\section{Determinant Coeficience}

In order to identify the $(X)$ variable of the credit amount against the $(Y)$ variable of the revenue of the credit service, the determinant analysis has been applied. The following is the result applying SPSS program version 17 :

Table 7

Model Summary

\begin{tabular}{|l|r|r|r|l|}
\hline Model & $\mathrm{R}$ & $\mathrm{R}$ Square & $\begin{array}{c}\text { Adjusted R } \\
\text { Square }\end{array}$ & $\begin{array}{c}\text { Std. Error of the } \\
\text { Estimate }\end{array}$ \\
\hline 1 & $.840^{\mathrm{a}}$ & .706 & .607 & 30622563.06474 \\
\hline
\end{tabular}

According to the table aforementioned, $r$ value $=0.840$ explaining that the total amount of the credit loan has been affecting the revenue of the credit service since $r$ square is 0.706 or $70.6 \%$ indicating that the variable $(X)$ total amount of the credit Ioan at KPRI-KPDK in Sukabumi has affected the variable $(Y)$ the revenue of the credit service which is $70.6 \%$

\section{Regression Analysis}

The Regression Analysis has applied SPSS (Statistical Package For Science and Society) program regarding the total amount of credit loan against the revenue of the credit service, as follows;

Nani Pujiastuti: The Effect of The Total Credit Receivable Upon The Revenue of Credit Service at KPRI-KPDK in Sukabumi 
Table 8

\section{Coefficients}

\begin{tabular}{|rr|r|r|r|r|r|}
\hline \multicolumn{2}{|l|}{ Model } & \multicolumn{2}{|c|}{ Unstandardized Coefficients } & \multicolumn{1}{c|}{$\begin{array}{c}\text { Standardized } \\
\text { Coefficients }\end{array}$} & $\mathrm{t}$ & Sig. \\
\cline { 3 - 5 } & \multicolumn{2}{|c|}{$\mathrm{B}$} & Std. Error & \multicolumn{1}{|c|}{ Beta } & & \\
\hline \multirow{2}{*}{1} & (Constant) & 39852081.767 & 33580282.837 & & 1.187 & .321 \\
& $\mathrm{X}$ & .123 & .046 & .840 & 2.681 & .075 \\
\hline
\end{tabular}

The aforementioned coefficient table has obtained the regression equation of $Y$ $=39,852,081,767+0.123(X)$. It determines that each 1.00 of the total of the credit has affected the revenue of the credit service $(Y)$ which is 0.123 . follows;

The aformentioned equation of the result of the analysis can be determined as

$$
\begin{aligned}
& Y=a+b(X) \\
& Y=39.852 \cdot 081,767+0,123(X) .
\end{aligned}
$$

\section{Hypothesis Test}

The hypthesis test has been applied when $P<0.05$, so that $H_{1}$ is accepted and $\mathrm{H}_{0}$ is rejected. And when $\mathrm{P}>0.05$, then $\mathrm{H}_{1}$ is rejected and $\mathrm{H}_{0}$ is accepted. Based on the result of the research, it has obtained the value of $P=0.075$ which is $P<0.10$, it means that $\mathrm{H}_{1}$ is rejected and $\mathrm{H}_{0}$ is accepted. Therefore the hypothesis is accepted which means that a positive effect has happened between the total of the credit and the revenue of the credit service and a significant effect has occured as well since $P$ $<0.05$

\section{CONCLUSION}

Based on the result of the research regarding the effect of the total credit upon the revenue of the credit service at KPRI-KPDK in Sukabumi, the conclusuions are as follows:

1. The total amount of the credit loan at KPRI-KPDK had been increasing since 2008 2009 , though it was decreased in 2010, moreover, it had been increasing again during $2011-2012$.

2. The revenue of the credit service at KPRI-KPDK in Sukabumi has been increasing every year eventhough it is not quite significant in percentage, but it is stable.

3. The Effect of the Total amount of the credit upon the revenue of the credit service is positive which is $r=0.840$, it explains that variable $(X)$, the effect of the total of the credit has affected the variable $(Y)$, the revenue of credit service which is $70.6 \%$. Based on the aforementioned data calculation, a regression equation of $\mathrm{Y}=$ $39.852 .081,767+0,123(X)$, it explains that each 1,00 number of the total amount of the credit occured has been affecting the revenue of credit service amounting to $\mathrm{Rp}$ $0,123,00$.

\section{REFERENCES}

Anwari Achmad, Mulyo Praptowo (1983), Kredit Kelayakan. Jakarta,

Hery, S.E., M.Si. 2013. Akuntansi Dasar 1\&2. Jakarta: PT. Grasindo.

Ikatan Akuntan Indonesia. 2008. Standar Akuntansi Keuangan. Jakarta: Salemba Empat.

Nani Pujiastuti: The Effect of The Total Credit Receivable Upon The Revenue of Credit Service at KPRI-KPDK in Sukabumi 
Keputusan Menteri Negara Koperasi Usaha Kecil dan Menengah Republik Indonesia no: 91/Kep./M.UKM/IX/2004

M. Rachmat Firdaus, (1985), Teori dan Analisa Kredit serta Ketentuan-Ketentuan tentang Kredit

Munawir. 2004. Analisa Laporan Keuangan. Edisi Keempat, Yogyakarta: Liberty

Sugiyono, Metode Penelitian Bisnis (Bandung : CV Alfabeta,2006).

Undang-Undang Perkoperasian. 2012. Bandung: Fokusmedia 
The Accounting Journal of BINANIAGA Vol. 02, No. 02, December 2017

PISSN: $2527-4309$

EISSN: $2580-1481$

This page intentionally be emptied.

Nani Pujiastuti: The Effect of The Total Credit Receivable Upon The Revenue of Credit Service at KPRI-KPDK in Sukabumi

Page : 76 